\title{
THE MOLECULAR DETECTION OF CITRUS VEIN PHLOEM DEGENERATION (CVPD) PATHOGEN (Liberobacter asiaticus) IN Diaphorina citri KUWAYAMA (HOMOPTERA : PSYLLIDAE) AND OTHER INSECTS ASSOCIATED WITH CITRUS PLANT
}

\author{
I Nyoman Wijaya*, Wayan Adiartayasa, and Made Sritamin \\ Department of Agroecotechnology, Faculty of Agriculture, Udayana University \\ *Corresponding author : wijayainyoman1956@gmail.com
}

\begin{abstract}
The research was coducted at Laboratory of Biotechnology Faculty of Agriculture Udayana University. The purpose of this research were to investigate moleculer detection of CVPD pathogen in its vector, other phytophagous insects on citrus cv, Siam and kemuning (Murraya paniculata L. Jack.). The result of this research showed that adults and nymphs of Diaphorina citri Kuw. could transmit CVPD disease, but the pathogen of CVPD could not be transovarially transmited. As a host of CVPD disease, kemuning could be source of infection. The adult of Toxoptera citricidus Kirkaldy and Maleuterpes dentipes Hell. could not potensial transmited CVPD disease.
\end{abstract}

Keywords: PCR, CVPD, D. citri, T. citricidus and M. Dentipes

\section{INTRODUCTION}

Citrus are priority horticulture commodity for cash crop development due to their good taste and nutition contens. Annual citrus productivity in Indonesia at the moment is still relatively low. i.e. $8.6-15$ tons per ha (Anonimus, 2012). This has been caused by CVPD by CVPD attack (Wirawan dkk., 2003). CVPD is the most important disease and a major cause of yield loss citrus plantations in almost all countries, especially Asia and Africa. In 1965 in Africa reduced citrus crops from CVPD diseases between 30 $\%-100 \%$. In Thailand damage of plants more than 95\%, while in Indonesia approximately three million damaged crops between the years $1960-1970$ (Julyasih, 2009). CVPD is a disease transmitted through a certain kind of insect known as $D$. citri (Tirtawidjaja an Suharsono, 1990). Recent studies indicated that CVPD pathogens are bacteria called Liberobacter that can be detected using 16S rDNA (Bove et al., 1996). The tranmission of CVPD in Bali has been rapid while the population of D. citri is very small. Other factor are considered contributive to the spread of CVPD ( Wijaya, 2003). The porpuses of this research were to undertake molecular detection regarding Liberobacter asiaticus among $D$. citri insects as well other insects assosiated with citrus plant. 


\section{MATERIALS AND METHODS}

The research was conducted in Biotechnology Labotarory Faculty of Agriculture, Udayana University. The research was intiated by collecting insects assosiated with citrus plant found in the field. Molecular analysis was then conducted on the insect collection which consisted of such species D. citri, Toxoptera citricidus Kirkaldy and Maleuterpes dentipes Hell. Each of these insects was put into different ependorf tubes. CTAB extract was then added and placed in a temperature room. The insect were incubated for 20 minutes at a temperature of $65^{\circ} \mathrm{C}$. Then, it was contrifuge at $6800 \mathrm{rpm}$ for five minutes. The resulted in two layer, i.e. the lower part consisting of organic substance and upper layer consisting of soution. This solution as then taken out for $90 \mathrm{ml}$ and was transformed to the new ependorf tube. A total of $10 \mathrm{ml} \mathrm{NaOAc}$ and 200 ul ethanol with absolute freezing temperature was added. Then it was kept inb freezer for 30 minutes. The secondcontrifuged was undertaken at 11500 rpm for 15 minutes. Then result was pellet and supernathan. The pellet was cleaned using 200 ul ethanol $70 \%$ centrifuged at $11500 \mathrm{rpm}$ for two minutes and the supernathan formed was discarded. The pellet was later dried for 15 minutes and 20 ul TE buffer (strrile distilled water). The isolated DNA was then suspended in buffer
TE solution which was then analysed using PCR. Finally, electroforesis were undertaken using agarose gel $1 \%$.

\section{RESULTS AND DISCUSION}

\section{The Existance of CVPD Pathogen in Diaphorina citri}

The result of CVPD molecular pathogen detection on $D$. citri indicated that adult and nympha $D$. citri positive contained Liberobacter (Figur 1.). This means that adult and nympha $D$. citri could be a vector of CVPD. D. citri insect had a pointed sucking stylet. When the insect tried suck the sap from a plant, some bacteria antered into the insect body undergoing process due to chemical substance in found in the insect body. When $D$. citri which contained this Liberobacter sucked the sap of a healthy citrus plant the bacteria were expelled at though its saliva. The spread of the disease occurs primarily by insect vector $D$. citri Kuwayama. Tipe spread of the disease can also be caused by the spread of citrus plant seeds that have been infected by pathogens CVPD disease (Capoor et al., 1974 in Mead, 1998). Typical symptoms of disease are the leaves become yellow, bones of leaves dark green, the leaves become more rigid and thiker than the healthy leaves and small ( Mead, 1998 ; Knapp et al., 1999). While the fruits becomes small and hard (Wirawan et al., 1998). CVPD affected plants leaves 
undergo chlorosis, the symptons resemble nitrogen deficiency, zinc, manganese and iron (Tirtawidjaja, 1983). CVPD disease is causing gram negative bacteria named that vectors CVPD disease in Africa, Liberobacter (Sandrine et al., 1996). Liberobacter africanum (Subandiyah et al., Pathogens can not be cultured in vitro, but 2000).

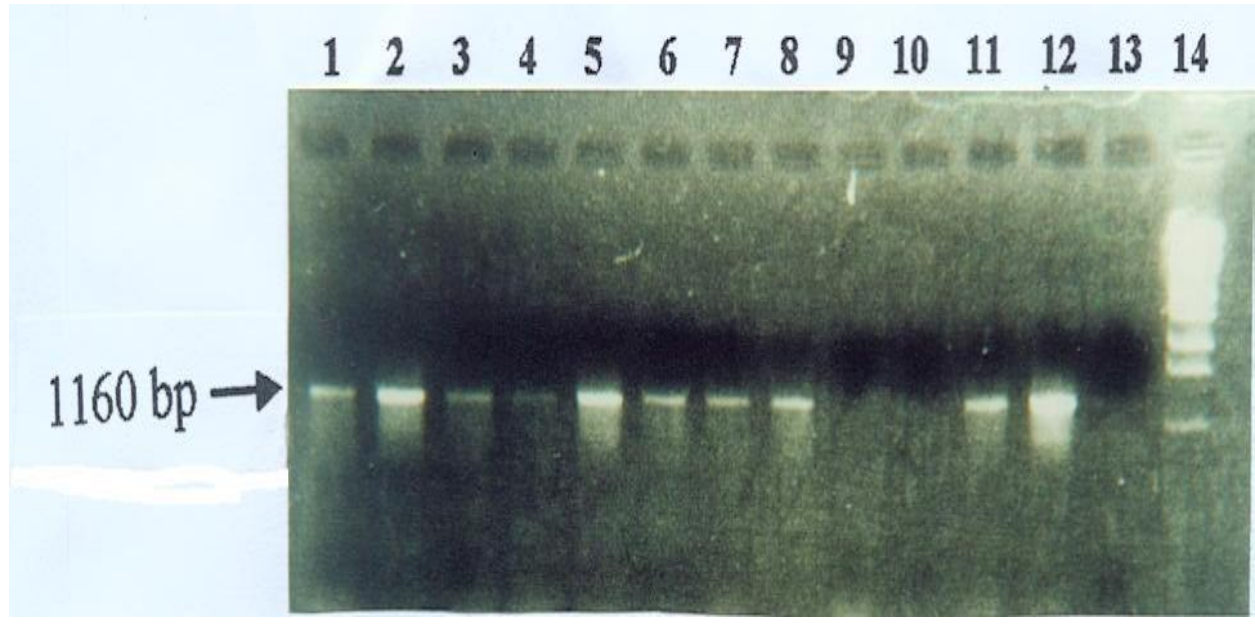

Fig. 1. Amplification Pathogen CVPD in D. citri, T. citricidus, M. dentipes, Leaves of Citrus and Kemuning by PCR Method. 1. Leaves of citrus in the field, 2. Leaves of citrus at laboratory, 3. Flash of citrus in the field, 4. Flash of citrus at laboratory, 5. Adult D. citri in the field, 6. Adult $D$. citri at laboratory, 7. Nimph $D$. citri in the field, 8. Nimph of D. citri at laboratory, 9. Adult of T. citricidus, 10. Adult of M. dentipes in the field, 11. Citrus seedling, 12. Leaves of Murraya paniculata, 13. Eggs of D. citri, 14. DNA marker

The Existance of CVPD Pathogen in T. citricidus and M. dentipes

The result of CVPD molecular detection on imago $T$. citricidus and $M$. dentipes showed the two species of insects did not contain Liberobacter (Figur 1). Consequently the two species of insects were not able to function as a CVPD vector. $T$. citricidus was in insect sucking the young leaves of citrus plant and they cannot act as a vector. This could happen because when the insect penetrated the plant using their stylet, it did not reach the layer where Liberobacter lived. On the other hand $M$. dentipes is an insect having their own mouth used to bite and chew and their saliva was not extracted on to the leaves when eating them.

\section{REFERENCES}

BPTP Balitbangtan Sulsel. (2012). Pengenalan Penyakit CVPD pada Tanaman Jeruk dan Upaya Pengendaliannya. Sulawesi Selatan: diakses pada diakses pada 27 Juni 2016. Diakses dari http://sulsel.litbang.pertanian.go.id/ind/ index.php/publikasi/panduan-petunjukteknis-brosur/119-pengenalanpenyakit-cvpd-pada-tanaman-jerukdan-upaya-penggendaliannya. 
Bove, J. M., Jogoueix, \& Garner, M. (1996). PCR Detection of two candidates Liberobacter species associated with greening diseases of citrus,. Molecular and Cellular Probes, 10, 43-50.

Hoy, A. M. (1998). Citrus Psylla. Entomology and Nematology. Departement University of Florida p.5. http://exlab7.centnem.ulf.edu/PestAl.er t.atlm.

Julyasih, K. S. M. (2009). Perkembangan Biologi Indonesia di Universitas Udayana. Udayana University Press. 209 hal.

Knapp, L. Joseph, Susan, H., Richard L., M. Hoy R. Clark., \& Kisinger, M. (1999). The Asia Citrus Psylla and Citrus Greening Disease. Integrated Pest Management Florida.

Mead, F. W. (1998). Asiatic Citrus Psyllid, Diaphorina citri Kuwayama. University of Florida. Cooperative Extension Service. Institute of Food and Agricultural Service. http://creaturesifas.ulf.edu.

Sandrine, J., Bove, J. M., \& Garnier. (1996). PCR Detection of The Two Candidatus Liberobacter SpeciesAssosiated with Greening Disease of Citrus. Moleculer and Celluler Probes., 1q0 : 43-50.

Subandiyah, S., Iwanami, T., \& Leki, S. (2000). Comparison of 16S r DNA and $16 \mathrm{~S} / 23 \mathrm{~S}$ Intergenic region squenses among citrus greening organism in Asia. Plant Disease. 84, 15-18.

Tirtawidjaja, S., \& Suharsojo, R. (1990). Penyakit CVPD merupakan bahaya laten bagi tanaman jeruk di Indonesia. Perlindungan Tanaman Menunjang Terwujudnya Pertanian Tangguh dan Kelestarian Lingkungan. PT. Agricon, 299-310.

Tirtawidjaja, S. (1983). Citrus Vein Phloem Degeneratian (CVPD) penyakit yang sangat merusak jeruk. Jurnal Litbang Pertanian II (1) . Jakarta. Balai Penelitian dan Pengembangan Pertanian.
Wijaya, I. N. (2003). Diaphorina citri Kuwayama (Homoptera : Psyllidae) : Bioekologi dan Peranannya Sebagai Vektor Penyakit CVPD (Citrus Vein Phloem Degeneration) Pada Tanaman Jeruk Siam. [Disertasi] Program Pascasarjana Institut Pertanian Bogor.

Wirawan, I. G. P., Sulistyowati, L., \&. Wijaya, I. N. (2004). Penyakit CVPD Pada Tanaman Jeruk : Analisis Baru Berbasis Bioteknologi. Denpasar. Udayana University Press. 139 hal.

Wirawan, I. G. P., Suprapta, D. N., Arya, N., \& Wijaya, I. N. (1998). Karakteristik Patogen dan Isolasi Gen untuk Ketahanan terhadap CVPD pada Tanaman Jeruk di Buleleng, Karangasem, Bangli, Gianyar dan Badung. Laporan Akhir Penelitian Kerjasama Fakultas Pertanian Universitas Udayana dengan Dinas Pertanian Tanaman Pangan Propinsi Daerah Tingkat I Bali Denpasar. 